by Shirley Developments, Ltd., which, as a result of rapid growth, now shows in its catalogue 30 instruments and 30 mechanical devices.

New instruments for research purposes included a new photomicrographic apparatus designed and made at the Institute, and also a polarizing lustre meter with which it is hoped to interpret how the eye judges lustre.

It was encouraging that a large proportion of the visitors on the open days came with the definite object in mind of seeing how the Institute's work made an impact on their own mill or works.

\title{
AGRICULTURAL INSTITUTE OF THE REPUBLIC OF IRELAND DIVISION OF PLANT SCIENCES AND CROP HUSBANDRY
}

$\mathrm{T}$ HE establishment, under the Agricultural (An Foras Talúntais) Act, 1958, of the Agricultural Institute of the Republic of Ireland, An Foras Talúntais, was announced in Nature, July 4, 1959. The Institute now announces major developments in the organization of the Division of Plant Sciences and Crop Husbandry. This will provide a wide coverage in the plant sciences field, catering for research in plant pathology, entomology (including nematology), plant breeding, plant protection, plant quality, weed control, and other general aspects of crop husbandry.

Mr. B. Crombie, at present in charge of the Plant Breeding Station of Cómhlucht Siúicre Éireann, Teo. (Irish Sugar Company), at Thurles, Co. Tipperary, has been appointed ehief of this Division. Mr. Crombie, a native of Offaly, gained his B.Agr.Se. degree with honours at the National University of Ireland in 1934 and was awarded a postgraduate scholarship. In 1937 he gained his M.Sc. degree for a thesis on "The Influence of Various Factors on the Time of Ripening of Wheat Varieties". While working under Prof. M. Caffrey, University College, Dublin, Mr. Crombie was responsible for the breeding of the well-known Glasnevin strains of perennial ryegrass and cocksfoot. He had been responsible for the organization of seed-breeding research and developments with Cómhlucht Siúicre Eireann, Teo., giving to the industry sugar-beet seeds of top quality. Mr. Crombie has published papers dealing with his research work in a number of scientific journals. $\mathrm{He}$ comes to his new post with a high reputation not only in plant breeding but also in plant science and crop-husbandry work in general.

By mutual agreement between the Council of An Foras Talúntais and the Industrial Research Committee of the Institute for Industrial Research and Standards, the facilities and equipment of the Cereals Laboratory at the latter Institute have been made available to An Foras Taluntais. This laboratory will devote special attention to the question of baking quality in wheat in relation to soil, manurial, climatic, varietal and cultural conditions, while in addition undertaking research on quality in other cereals. The general supervision of this laboratory for An Foras Talúntais will be in the hands of the director of the Institute for Industrial Research and Standards, Mr. D. T. Flood. Mr. P. A. Spillane has been appointed a senior research officer on the staff of An Foras Talúntais and will be head of the laboratory. Other appointments to this Unit are those of Miss $\mathbf{H}$. McGovern as research officer and Misses K. McGrath and E. Cooper as technicians. Mr. Spillane graduated from University College, Dublin, with honours in physics and chemistry in 1936. He has a wide experience of research and general operational work in the flour-milling industry and is the author of a number of scientific papers dealing with this work.
It has been agreed in principle between the Board of Cómhlucht Siúicre Érireann, Teo., and the Council of An Foras Talúntais that the sugar-beet breeding research facilities at Thurles and the Nematology Laboratory at Carlow of the Irish Sugar Company will be integrated with An Foras Talúntais. These centres have already been placed under the scientific direction of An Foras Talúntais pending the conclu. sion of arrangements by the staffs of the organizations concerned. This arrangernent places at the disposal of the Agricultural Institute the scientific staff and extensive offices, laboratory and greenhouse facilities and equipment which have been developed at these centres over a number of years. While the sugar-beet seed research programme will be continued and expanded at Thurles by An Foras Talúntais on behalf of Cómhlucht Siúicre Éireann, Teo., this centre will also act as headquarters of the Division, with the resulting development of research services in general plant science work apart from those needed for sugar-beet research.

The nematology laboratory at Carlow which provides well-developed facilities for this sphere of research will also be used in the general research programme of the Institute. Dr. J. J. Duggan has been appointed senior research officer in charge of the Nematology Unit of the Institute now located at University College, Dublin. Dr. Duggan is well known for his research work in nematology on which he has published a number of scientific papers, and the Unit at Carlow is now under his scientific direction.

A Plant Pathology Unit has been established. Dr. J. B. Loughnane, Department of Plant Pathology, University College, Dublin, is acting as adviser for this aspect of the activities of the Institute. Mr. $\mathrm{P}$. Cunningham and Mr. C. Comerford are now working under Dr. Loughnane in the Plant Pathology Unit, while Mr. T. E. Mulligan, previously on the staff of the Rothamsted Experimental Station, joined the staff of the Unit on October l. Associated Seed Growers, Ltd., have generously offered a grant for the investigation of the diseases of a number of crops such as kale and mangels. This offer has been accepted by the Council of the Institute and investigations are already under way.

Arrangements are also being completed for placing an Applied Plant Genetics Research Unit at the Kells Ingram Farm of the University of Dublin, working under the general direction of Mr. G. W. P. Dawson, head of the new Department of Genetics, Trinity College, Dublin. This Unit will deal with some of the more practical aspects of plant genetics. Mr. V. Connolly has been appointed research officer in this Division. Arrangements are proceeding with the organization of the other departments of the Division, and it is hoped to have a full research programme under way during the coming year. 